\title{
Inovasi Pembuatan Cookies Kaya Gizi Dengan Proporsi Tepung Bekatul dan Tepung Kedelai
}

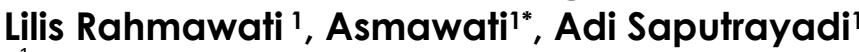

${ }^{1}$ Teknologi Hasil Pertanian, Universitas Muhammadiyah Mataram

Corresponding Author: asmawatiraba@gmail.com

\section{INFO ARTIKEL}

RiwayatArtikel:

Diterima: 06-01-20

Disetujui: 20-02-20

\section{Kata Kunci:}

Cookies

Tepung Bekatul

Kedelai

\section{A. LATAR BELAKANG}

Cookies merupakan makanan yang cukup popular, karena dapat dimakan kapan saja dan disukai oleh semua kalangan dan memiliki daya simpan yang relatif panjang. Menurut SNI 01-2973-1992 (2011), Cookies merupakan salah satu jenis biskuit yang terbuat dari adonan lunak, berkadar lemak tinggi, relatif renyah bila dipatahkan dan bertekstur padat.

Indonesia saat ini menduduki peringkat kedua terbesar di dunia sebagai importer gandum. Jika keadaan ini dibiarkan, ketergantungan pangan dari luar negeri dapat meningkatkan pengeluaran devisa negara. Oleh karena itu perlu upaya mengurangi ketergantungan terhadap penggunaan tepung terigu.
Salah satu cara untuk mengurangi kebutuhan tepung terigu pada pembuatan cookies yaitu dengan mensubstitusi sebagian atau seluruh tepung terigu dengan tepung lain misalnya tepung bekatul dan tepung kedelai. Hal ini juga merupakan salah satu upaya dalam memanfaatkan limbah bekatul dan penganekaragaman produk cookies (Mulyani $d k k$., 2015).

Bekatul merupakan bahan pangan lokal yang mengandung serat pangan yang tinggi. Kandungan serat dalam 100 gr bekatul mencapai 25,3 gr (Rao, 2000). Disamping itu, bekatul mengandung karbohidrat, protein, mineral, lemak, vitamin B kompleks (B1, B2, B3, B5, B6, dan B15), 
komponen-komponen bioaktif termasuk nitrilosid (zat antikanker), dan dietary fiber (serat pangan). Salah satu kandungan tertinggi di dalam bekatul adalah vitamin B15 yang sanggup mengoptimalkan kerja aneka organ tubuh manusia. Nilai gizi yang terkandung dalam bekatul ternyata mampu mengalahkan nilai gizi dalam beras putih. Selama ini mayoritas manusia mengkonsumsi beras putih, tidak heran jika sekarang banyak orang yang terserang berbagai penyakit, seperti konstipasi, kanker kolon, hipertensi, hiperkolesterol, diabetes mellitus, dan sebagainya. Kandungan gizi utama dalam beras putih adalah karbohidrat, wajar apabila tubuh masih membutuhkan asupan lain untuk memenuhi tuntutan pemenuhan gizi dalam tubuh, misalnya serat, vitamin B kompleks, tokoferol, dan sebagainya yang justru ada dalam bekatul (Ardiansyah, 2004).

Pemanfaatan bekatul sebagai bahan tambahan dalam pembuatan makanan ringan seperti cookies, selain dapat meningkatkan nilai gizi produk, juga dapat memperbaiki tampilan warna, cita rasa yang lebih enak, dan akan memberikan pengaruh fisiologis yang baik bagi tubuh. Pembuatan cookies bekatul dapat dipadukan dengan bahan bebas gluten seperti tepung kedelai sebagai pengganti tepung terigu sehingga cookies yang dihasilkan memiliki nilai gizi yang tinggi terutama protein dan serat, aman dikonsumsi serta dapat menjadi alternative pangan fungsional.

Tepung kedelai merupakan hasil olahan dari biji kedelai, kaya akan protein dan sebagai sumber lemak nabati yang sangat penting peranannya dalam kesehatan tubuh. Kandungan protein dalam biji kedelai dalam 100 gram bahan sebesar 34,9 gr, dan lemak nabati sebesar 38,1 gr, tinggi kalsium yaitu $227 \mathrm{mg}$, fosfor sebesar $585 \mathrm{mg}$, karbohidrat sebesar 34,8 gr, vitamin A sebesar 33 mcg. Protein pada tepung kedelai sebesar 41,7 \%, karbohidrat sebesar 23,3 \% dan lemak sebesar 27,1 \% (Suprapti, 2003). Tepung kedelai memiliki kelemahan yaitu adanya aroma dan cita rasa langu. Oleh sebab itu, perlu adanya bahan campuran yang dapat menutupi aroma dan cita rasa langu tersebut (Dahlia dkk., 2007).

Pembuatan biskuit dengan bahan dasar tepung terigu sebanyak 100 gr dengan variasi penambahan tepung bekatul o\% sampai dengan 20\% menunjukkan bahwa semakin tinggi penambahan bekatul maka semakin tinggi pula kadar protein dari biskuit tersebut (Wulandari dan Handarsari 2010), sedangkan Hasil penelitian Layla (2015) menginformasikan bahwa perlakuan terbaik dengan kadar protein tertinggi diperoleh pada perlakuan (formulasi 100\% tepung kedelai : o\% tepung mocaf dan ekstrak jahe 3\%) yang mencapai 13,019\%.

Berdasarkan uraian di atas, telah dilakukan penelitian mengenai proporsi tepung bekatul dan tepung kedelai pada pembuatan cookies kaya gizi.

\section{B. METODE PENELITIAN}

Metode yang digunakan dalam penelitian ini adalah metode Eksperimental dengan percobaan di Laboratorium, dirancangan dengan menggunakan Rancangan Acak Lengkap (RAL) atau Completeli Rondamizet Design dengan perlakuan proporsi tepung bekatul dan tepung kedelai dalam pembuatan cookies kaya giziyang terdiri dari 6 perlakuan sebagai berikut: $\mathrm{Po}=100 \%$ tepung terigu (sebagai perlakuan kontrol), $\mathrm{P} 1=10 \%$ tepung bekatul $+30 \%$ tepung kedelai, $\mathrm{P} 2=15 \%$ tepung bekatul $+25 \%$ tepung kedelai, $\mathrm{P}_{3}=20 \%$ tepung bekatul $+20 \%$ tepung kedelai, $\mathrm{P}_{4}=25 \%$ tepung bekatul $+15 \%$ tepung kedelai, $\mathrm{P}_{5}=30 \%$ tepung bekatul $+10 \%$ tepung kedelai. Setiap perlakuan membutuhkan berat sampel 250 gram (campuran tepung bekatul dan tepung kedelai 40\%) ditambah dengan tepung terigu 60\%). Data hasil pengamatan dianalisis dengan menggunakan Analisis Keragaman (Analisis of Variance = Anova) pada taraf nyata $5 \%$ dan bila terdapat pengaruh beda nyata maka diuji lanjut dengan uji Beda Nyata Jujur (BNJ) pada taraf nyata sama yaitu 5\% (Hanafiah, 2001).

\section{Bahan dan Alat Penelitian \\ a. Bahan}

Bahan-bahan yang digunakan dalam pembuatan cookies adalah tepung bekatul, tepung kedelai, tepung terigu, gula pasir, air, margarin, telur, dan susu skim.

\section{b. Alat}

Alat yang digunakan dalam pembuatan cookies adalah timbangan analitik, mixer, roll, sendok, loyang, ayakan, pisau, wajan, oven pemanggang,dan kompor.

\section{Pelaksanaan Penelitian}

Penelitian ini dibagi menjadi 3 (tiga) Tahapan sebagai berikut :

\section{Pembuatan Tepung Kedelai}

Proses pembuatan tepung kedelai mengacu pada metode (Warisno dan Dahana, 2010) dapat dilihat pada Gambar 1 .

\section{Pembuatan Tepung Bekatul}

Proses pembuatan tepung bekatul mengacu pada metode (Mulyani $d k k, 2015)$ dapat dilihat pada Gambar 2.

\section{Pembuatan Cookies}

Proses pembuatan cookies pada penelitian ini mengacu pada metode (Wulandari dan Handarsari, 2010) yang sudah dimodifikasi, dapat dilihat pada Gambar 3 . 


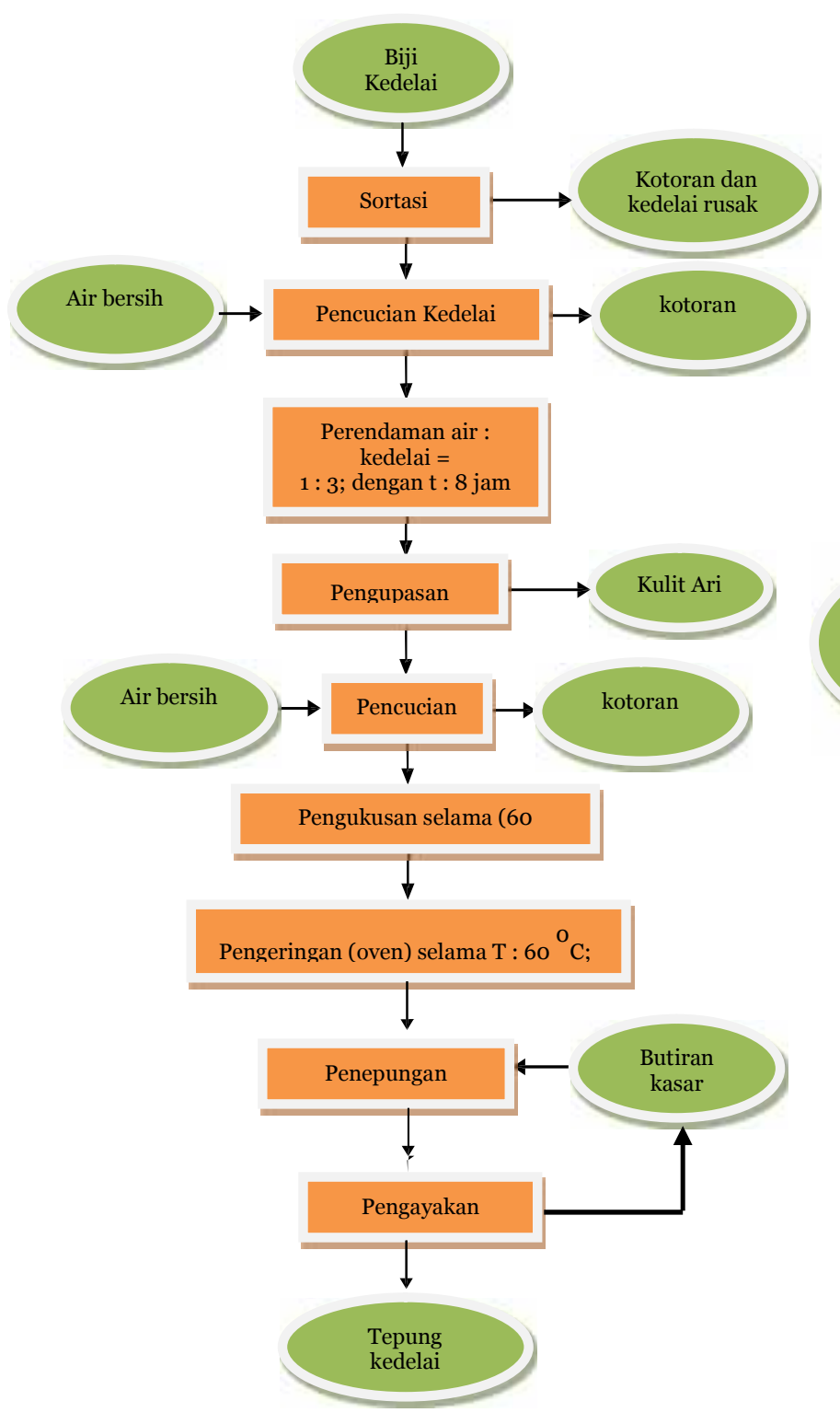

Gambar 1. Diagram Alir Proses Pembuatan Tepung Kedelai

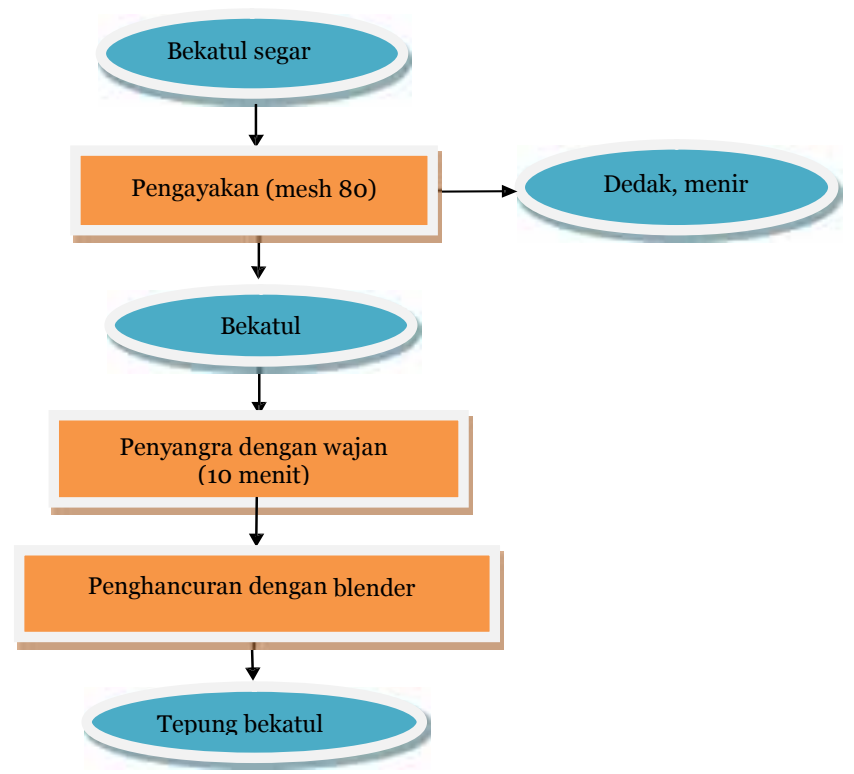

Gambar 2. Diagram Alir Proses Pembuatan Tepung Bekatul

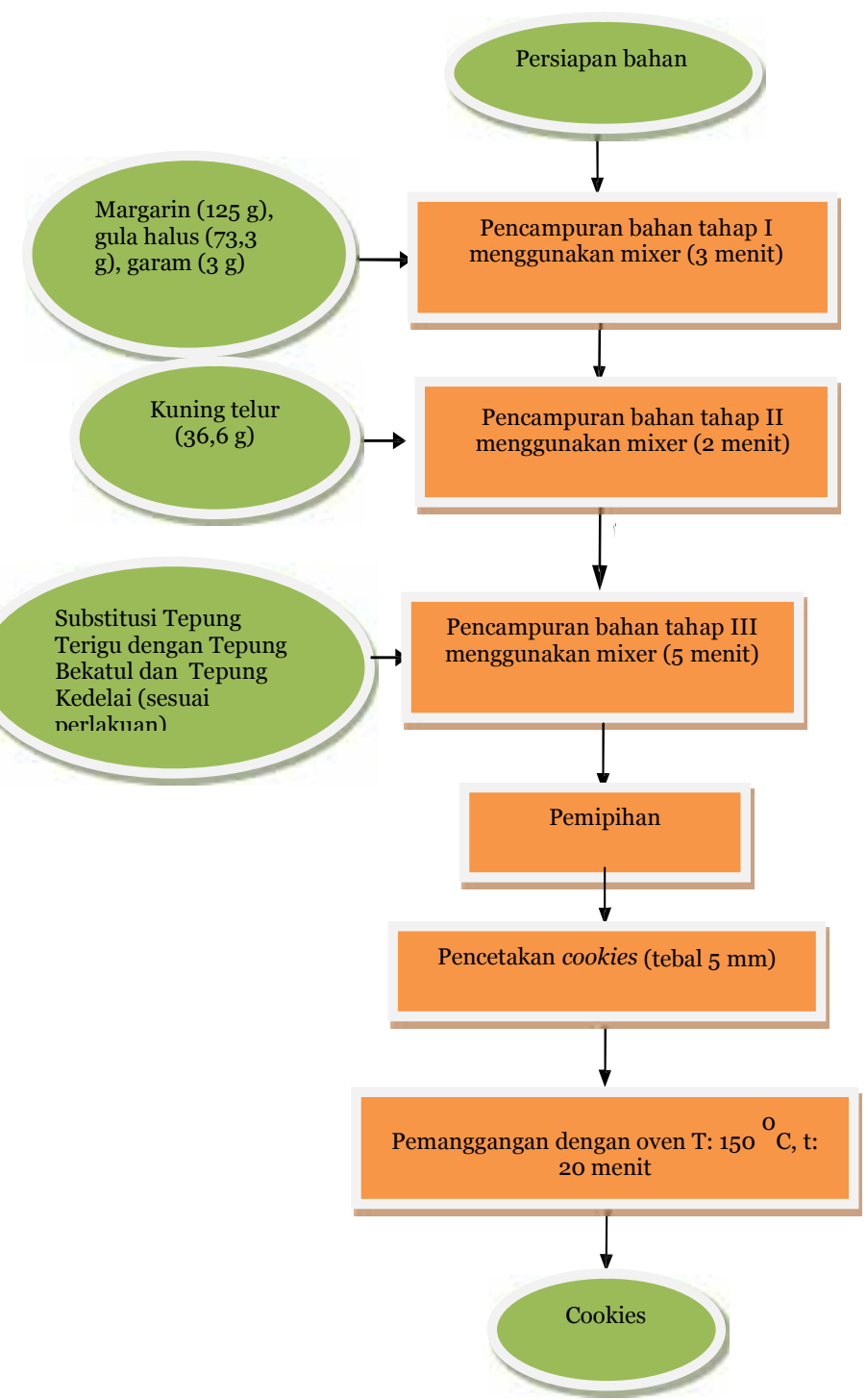

Gambar 3. Diagram Alir Proses Pembuatan Cookies Modifikasi

\section{Parameter Pengamatan}

Parameter dalam penelitian ini meliputi sifat kimia berupa: kadar air, kadar abu, dan kadar protein (Sudarmadji, dkk 1997) serta sifat organoleptik berupa rasa, aroma, warna dan tekstur cookies dengan metode hedonic dan scoring (Rahayu, 1997).

\section{HASIL DAN PEMBAHASAN Sifat Kimia Cookies}

\section{a. Kadar Air}

Perlakuan proporsi tepung bekatul dan tepung kedelai tidak memberikan rpengaruh secara nyata terhadap kadar air cookies, walaupun hasil penelitian menunjukkan angka yang semakin menurun seiring dengan semakin tingginya proporsi penambahan tepung bekatul. Grafik hubungan pengaruh proporsi tepung bekatul dan tepung kedelai terhadap kadar air cookies dapat dilihat pada Gambar 4 


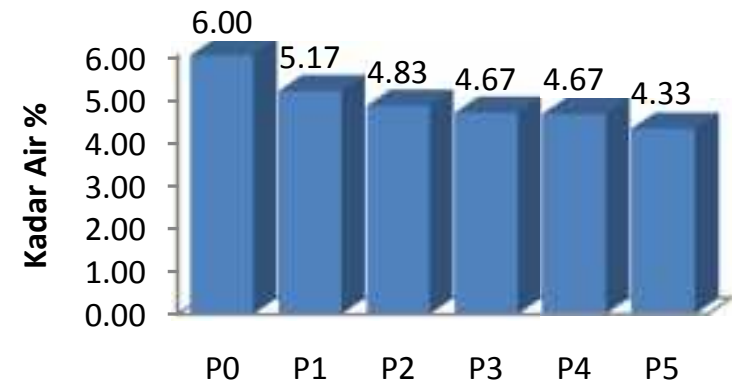

Proporsi Tepung Bekatul dan Tepung Kedela (\%)

Gambar 4. Grafik Hubungan Pengaruh Proporsi Tepung Bekatul Dan Tepung Kedelai Terhadap Kadar Air Cookies

Gambar 4 menunjukkan bahwa kadar air tertinggi diperoleh pada perlakuan Po (tanpa penambahan tepung bekatul dan tepung kedelai) sebesar 6.00\%, Sedangkan kadar air terendah diperoleh pada perlakuan $\mathrm{P}_{5}$ (proporsi 30\% tepung bekatul dan 10\% tepung kedelai) sebesar 4.33\%.

Tingginya kadar air pada perlakuan Po (tanpa penambahan tepung bekatul dan tepung kedelai). Hal ini dikarenakan perlakuan ini menggunakan 100\% tepung terigu, dimana menurut BSN (2000) tepung terigu memiliki kadar air yang tinggi yaitu sebesar 12,2\% lebih tinggi dibandingkan dengan kadar air pada tepung kedelai sebesar 6,6\% (Napitupulu, dkk. 2013) dan tepung bekatul sebesar 6,7\% (Rao, 2000).

Menurut Standar Nasional Indonesia (SNI) persyaratan kadar air cookies adalah maksimal 5\%. Dari penelitian ini, sampel yang memenuhi persyaratan Standar Nasional Indonesia (SNI) adalah perlakuan P2 (15\% tepung bekatul dan 25\% tepung kedelai) sebesar 4,83\%, perlakuan $\mathrm{P}_{3}$ (20\% tepung bekatul dan 20\% tepung kedelai), dan perlakuan $\mathrm{P}_{4}$ (25\% tepung bekatul dan 15\% tepung kedelai) sebesar $4.67 \%$, serta perlakuan $\mathrm{P}_{5}$ (30\% tepung bekatul dan 10\% tepung kedelai) sebesar 4,33\%, sedangkan perlakuan yang tidak memenuhi Standar Nasional Indonesia (SNI) adalah perlakuan Po (tanpa tepung bekatul dan tepung kedelai) sebesar $6.00 \%$ dan perlakuan P1 (10\% tepung bekatul dan 30\% tepung kedelai) sebesar $5,17 \%$.

\section{b. Kadar abu}

Perlakuan proporsi tepung bekatul dan tepung kedelai tidak berpengaruh secara nyata terhadap kadar abu cookies, walaupun hasil penelitian menunjukkan angka yang semakin tinggi seiring dengan semakin tingginya proporsi penambahan tepung bekatul. Grafik hubungan pengaruh proporsi tepung bekatul dan tepung kedelai terhadap kadar abu cookies dapat dilihat pada Gambar 5 .

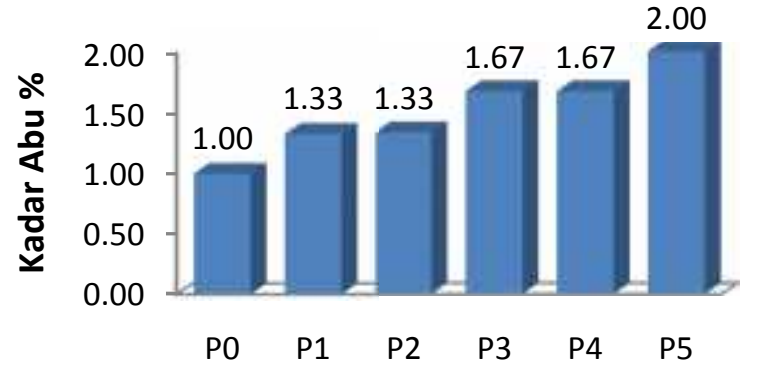

Proporsi Tepung Bekatul dan Tepung Kedelai (\%)

Gambar 5. Grafik hubungan pengaruh proporsi tepung bekatul dan tepung kedelai terhadap kadar abu cookies

Pada Gambar 5 menunjukkan bahwa perlakuan $\mathrm{P}_{5}$ (proporsi tepung bekatul 30\% dan tepung kedelai 10\%) memiliki kadar abu tertinggi sebesar 2.00\%, sedangkan kadar abu terendah diperoleh pada perlakuan Po (tanpa penambahan tepung bekatul dan tepung kedelai) yaitu sebesar $1.00 \%$.

Tingginya kadar abu pada perlakuan $\mathrm{P}_{5}$ (proporsi 30\% tepung bekatul dan 10\% tepung kedelai) ini disebabkan karena tingginya kandungan mineral yang terdapat dalam tepung bekatul yaitu sebesar 8.3 gr dalam 100 gr bahan (Rao, 2000). Sehingga semakin tinggi penambahan tepung bekatul maka kadar abu cookies akan semakin meningkat. Berdasarkan Standar Nasional Indonesia (SNI 01-2973-1992-2011) kadar abu cookies adalah maksimal 1,5\%. Dari penelitian tersebut, perlakuan yang memenuhi Standar SNI diperoleh pada perlakuan Po sebesar (1.00\%), perlakuan P1 dan P2 sebesar 1.33\%. Sedangkan perlakuan yang tidak memenuhi Standar SNI adalah perlakuan $\mathrm{P}_{3}$ dan $\mathrm{P}_{4}$ sebesar $1.67 \%$, dan perlakuan $\mathrm{P}_{5}$ sebesar $2.00 \%$.

\section{c. Kadar Protein}

Grafik hubungan pengaruh proporsi tepung bekatul dan tepung kedelai terhadap kadar protein cookies dapat dilihat pada Gambar 6.

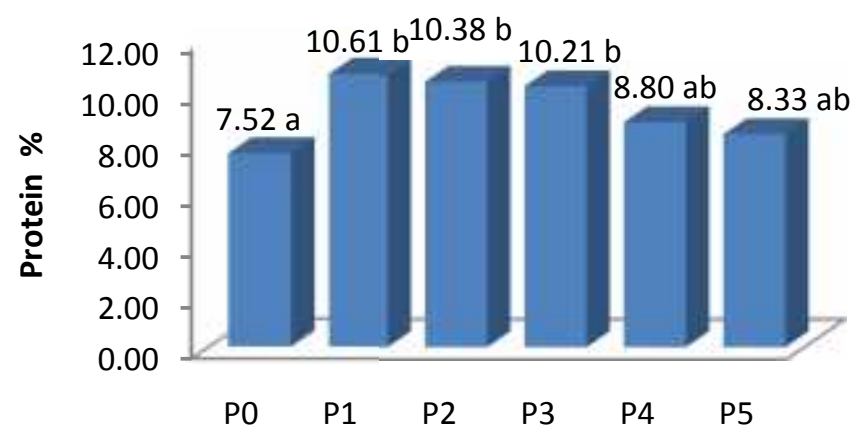

Proporsi Tepung Bekatul dan Tepung Kedelai (\%)

Gambar 6. Grafik hubungan pengaruh proporsi tepung bekatul dan tepung kedelai terhadap kadar protein cookies 
Pada Gambar 6 menunjukkan bahwa kadar protein tertinggi diperoleh pada perlakuan P1 (10\% tepung bekatul dan 30\% tepung kedelai) sebesar $10.61 \%$, sedangkan kadar protein terendah diperoleh pada perlakuan Po (tanpa penambahan tepung bekatul dan tepung kedelai) sebesar $7 \cdot 52 \%$.

Tingginya kadar protein cookies pada perlakuan P1 disebabkan karena tingginya proporsi tepung kedelai yang ditambahkan yaitu sebesar (30\%). Menurut Cahyadi (2007) kandungan protein tepung kedelai yang cukup tinggi sangat berpengaruh terhadap cookies yang dihasilkan. Sehingga semakin banyak tepung kedelai yang ditambahkan, maka semakin tinggi kadar protein yang terkandung pada cookies.

Rendahnya kadar protein pada perlakuan Po disebabkan karena perlakuan Po tidak ditambahkan tepung kedelai maupun tepung bekatul (100\% tepung terigu). Menurut BSN (2000) Tepung terigu memiliki kandungan protein paling rendah sebesar (9.61\%) dibandingkan dengan tepung bekatul $(16,5 \%)$ dan tepung kedelai $(41,7 \%)$ (Napitupulu $d k k, 2013)$.

Berdasarkan Standar SNI 01-2973-1992 (2011), bahwa kandungan protein cookies minimum 9\%. Dari penelitian tersebut, perlakuan yang memenuhi SNI adalah perlakuan $\mathrm{P} 1$ sebesar $10.61 \%$, perlakuan P2 sebesar $10.38 \%$, dan perlakuan $\mathrm{P}_{3}$ sebesar $10.21 \%$. sedangkan perlakuan yang tidak memenuhi SNI adalah perlakuan Po sebesar $7.52 \%$, perlakuan $\mathrm{P}_{4}$ sebesar 8.80\%, dan perlakuan $\mathrm{P}_{5}$ sebesar 8.33\%.

\section{Sifat Organoleptik Cookies}

\section{a. Warna}

Grafik hubungan pengaruh proporsi tepung bekatul dan tepung kedelai terhadap skor nilai warna cookies dapat dilihat pada Gambar 7.

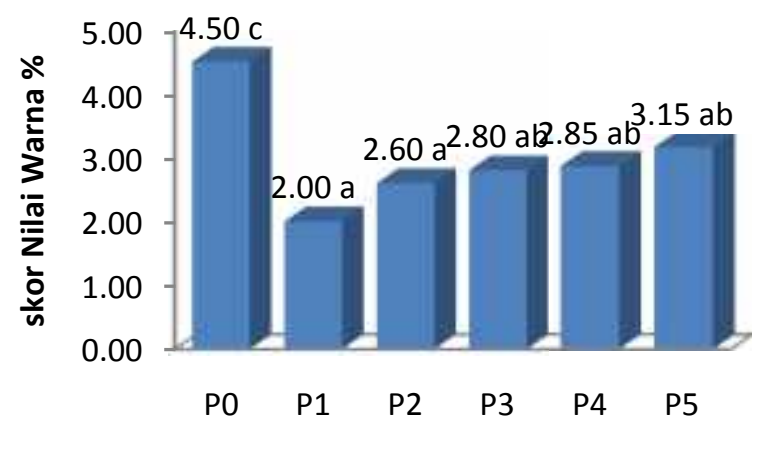

Proporsi Tepung Bekatul dan Tepung Kedelai

(\%)

Gambar 7. Grafik hubungan pengaruh proporsi tepung bekatul dan tepung kedelai terhadap skor nilai warna cookies.

Gambar 7 menunjukkan bahwa proporsi tepung bekatul dan tepung kedelai berpengaruh secara nyata terhadap skor nilai warna cookies. Hasil penilaian panelis terhadap warna cookies menghasilkan tingkat kesukaan dari 2 (coklat tua) sampai dengan 4.5 (agak coklat) mendekati krem.

Semakin tinggi proporsi tepung bekatul dan semakin rendah tepung kedelai yang ditambahkan maka skor nilai warna cookies yang dihasilkan akan semakin tinggi, yaitu dari 2,0 dg kriteria berwarna coklat pada perlakuan P1 (proporsi $10 \%$ tepung bekatul dan $30 \%$ tepung kedelai) sampai dengan 3,15 dengan kriteria coklat muda pada perlakuan $\mathrm{P}_{5}$ (proporsi $30 \%$ tepung bekatul dan $10 \%$ tepung terigu), sedangkan perlakuan Po (100 \% tepung terigu) yang merupakan perlakuan kontrol mendapatkan skor nilai tertinggi sebesar 4,5 dengan kriteria krem.

Rendahnya skor penilaian panelis terhadap warna cookies pada perlakuan P1, disebabkan karena pada perlakuan tersebut proporsi tepung kedelainya tinggi (30 \%) dan tepung bekatulnya rendah (10 \%). Kadar protein pada tepung kedelai yang tinggi menyebabkan terjadinya reaksi Mailard. Reaksi Maillard terjadi karena adanya reaksi antara karbohidrat (gula pereduksi) dengan gugus amino (protein) pada suhu tinggi. Reaksi Maillard menghasilkan produk berwarna coklat yang disebut melanoidin. Pengaruh suhu dan lama pemanggangan berkaitan juga dengan reaksi karamelisasi (Winarno, 2004).

\section{b. Aroma}

Grafik hubungan pengaruh proporsi tepung bekatul dan tepung kedelai terhadap tingkat kesukaan aroma cookies dapat dilihat pada Gambar 8.

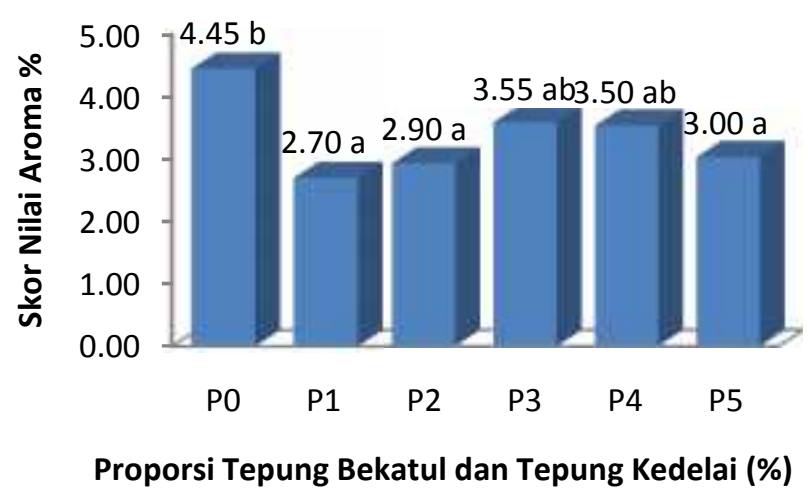

Gambar 8. Grafik hubungan pengaruh proporsi tepung bekatul dan tepung kedelai terhadap skor nilai aroma cookies.

Gambar 8 menunjukkan bahwa proporsi tepung bekatul dan tepung kedelai berpengaruh secara nyata terhadap skor nilai aroma cookies. Hasil penilaian terhadap aroma cookies menghasilkan tingkat kesukaan panelis dari skor nilai 2.70 (agak suka) sampai dengan 3,55 (mendekati suka), sedangkan pada perlakuan Po (100 \% tepung terigu) yang 
merupakan perlakuan kontrol mendapatkan skor penilaian tertinggi yaitu sebesar 4,45 (suka, mendekati sangat suka).

Semakin tinggi proporsi tepung kedelai yang ditambahkan menyebabkan tingkat kesukaan panelis terhadap aroma cookies menurun. Hal ini disebabkan karena kedelai mengandung enzim lipoksigenase dan asam lemak tidak jenuh rantai panjang (asam linoleat dan linolenat). Pada saat penepungan, enzim lipoksigenase akan aktif dan mempercepat peroksidasi asam lemak tak jenuh pada kedelai sehingga menghasilkan aroma tengik (Mandal $d k k$ 2014), sehingga tidak disukai oleh panelis.

\section{c. Tekstur}

Grafik hubungan pengaruh proporsi tepung bekatul dan tepung kedelai terhadap tekstur cookies dapat dilihat pada Gambar 9.

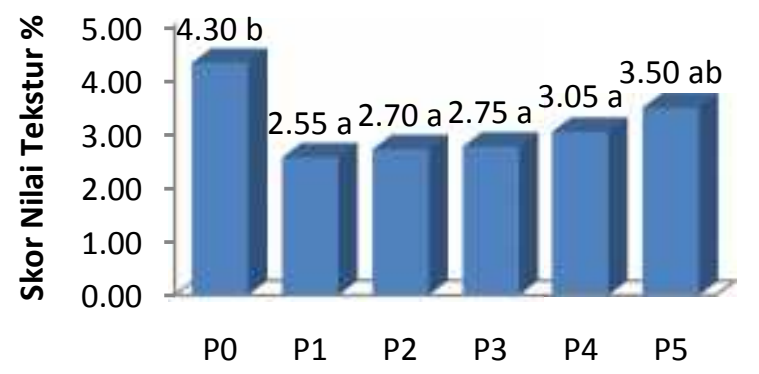

Proporsi Tepung Bekatul dan Tepung Kedelai (\%)

Gambar 9. Grafik hubungan pengaruh proporsi tepung bekatul dan tepung kedelai terhadap skor nilai cookies

Gambar 9 menunjukkan bahwa proporsi tepung bekatul dan tepung kedelai berpengaruh nyata terhadap tingkat kesukaan panelis pada tekstur cookies. Hasil penilaian skor nilai tekstur tertinggi diperoleh pada perlakuan $\mathrm{P}_{5}$ (proporsi tepung bekatul $30 \%$ dan tepung kedelai $10 \%$ ) sebesar 3,50 dengan kriteriatia agak renyah dan terendah diperoleh pada perlakuan $\mathrm{P}_{1}$ (10\% tepung bekatul dan $30 \%$ tepung kedelai) sebesar $2.55 \%$ dengan kriteria kurang renyah, sedangkan pada perlakuan Po (100 \% tepung terigu) yang merupakan perlakuan kontrol mendaparkan skor nilai teringgi yaitu sebesr 4,30 dengan kriteria renyah.

Berdasarkan hasil analisa kadar protein cookies menunjukkan bahwa, pada perlakuan Po memiliki kandungan protein terendah yaitu sebesar $7,52 \%$ dan perlakuan P1 memiliki kandungan protein tertinggi sebesar 10,61\% (Gambar 6). Semakin tinggi kandungan protein pada suatu bahan akan mengakibatkan tekstur cenderung kurang renyah atau keras. . Hal ini sesuai dengan pendapat Andarwulan dkk (2011), Kerenyahan cookies dipengaruhi oleh kandungan protein, amilosa dan amilopektin. Protein mempunyai sifat hidrofilik yaitu mempunyai daya serap air yang tinggi. Adanya penyerapan air diakibatkan adanya gugus karboksil pada protein, sehingga semakin tinggi kandungan protein dalam cookies maka teksturnya cenderung lebih keras atau kurang renyah.

\section{d. Rasa}

Grafik hubungan pengaruh proporsi tepung bekatul dan tepung kedelai terhadap rasa cookies dapat dilihat pada Gambar 10.

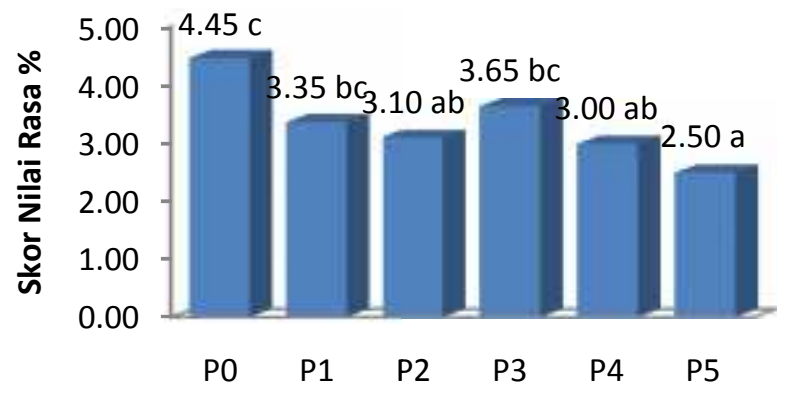

Proporsi Tepung Bekatul dan Tepung Kedelai

(\%)

Gambar 10. Grafik hubungan pengaruh proporsi tepung bekatul dan tepung kedelai terhadap skor nilai rasa cookies

Pada Gambar 10 menunjukkan bahwa proporsi tepung bekatul dan tepung kedelai berpengaruh secara nyata terhadap rasa cookies. Hasil penilaian panelis terhadap rasa cookies menghasilkan tingkat kesukaan dari skor nilai 2.50\% (agak enak) pada perlakuan $\mathrm{P}_{5}$ (proporsi tepung bekatul $30 \%$ dan tepung kedelai 10 \%) sampai skor nilai 3,65 ( mendekati enak) pada perlakua $\mathrm{P}_{3}$ ( proporsi tepung bekatul $20 \%$ dan tepung kedelai 20\%), sedangkan pada perlakuan Po (100 \% tepung terigu) yang merupakan perlakuan kontrol mendapatkan skor $4.45 \%$ (enak, mendekati sangat enak.

Menurut Swastika (2009), semakin tinggi penambahan tepung bekatul menyebabkan tingkat kesukaan panelis terhadap rasa cookies menurun. Karena semakin banyak penambahan tepung bekatul mengakibatkan rasa cookies yang dihasilkan semakin pahit karena terdapat kandungan saponin dalam bahannya.

Tingginya tingkat kesukaan panelis terhadap rasa cookies pada perlakuan Po disebabkan karena cookies dibuat dari $100 \%$ tepung terigu sebagai bahan dasar. Panelis sudah terbiasa mengkonsumsi cookies yang berbahan dasar tepung terigu. 


\section{SIMPULAN DAN SARAN SIMPULAN}

Berdasarkan hasil penelitian dapat disimpulkan hal-hal berikut :

a. Perlakuan proporsi tepung bekatul dan tepung kedelai berpengaruh secara nyata terhadap sifat kimia (kadar protein) dan sifat organoleptik seperti warna, aroma, rasa dan tekstur cookies, tetapi tidak berpengaruh secara nyata terhadap sifat kimia (kadar air dan kadar abu) cookies yang diamati.

b. Semakin tinggi proporsi tepung bekatul yang ditambahkan dan semakin rendah tepung kedelainya, maka kadar abu cookies semakin meningkat dan kadar protein dan kadar air semakin menurun

c. Perlakuan terbaik dan disukai panelis dari segi sifat organoleftik serta memenuhi SNI, diperoleh pada cookies perlakuan $\mathrm{P}_{3}$ (proporsi tepung bekatul20\% dan tepung kedelai 20\%) menghasilkan cookies yang disukai oleh panelis dari segi warna coklat muda, aroma suka, tekstur agak renyah, dan rasa enak.

\section{SARAN}

Berdasarkan hasil penelitian dapat disarankan bahwa untuk mendapatkan cookies yang disukai panelis disarankan menggunakan perlakuan dengan proporsi tepung bekatul dan tepung kedelai sebesar 50\% : 50\%.

\section{DAFTAR RUJUKAN}

[1] Ardiansyah. Sehat dengan Mengonsumsi Bekatul. Diakses dari http://www.gizi.net. 2004.

[2] Astawan M. Pangan Fungsional untuk Kesehatan yang Optimal. Fakultas Teknologi Pertanian IPB. Bogor. 2011.

[3] Badan Standarisai Nasional (SNI) 01-2973-1992. Standar Mutu Cookies. Jakarta. 2011.

[4] Badan Standarisasi Nasional. Komponen Mutu Tepung Terigu. (SNI 01-3751-2000/Rev). Jakarta: Departemen Perindustrian. 2000.

[5] Cahyadi, W. Kedelai Khasiat Dan Teknologi. Jakarta: Bumi Aksara. Columbia University Press, New York. 2007.

[6] Dahlia., Mutiara., Rusilanti. Membuat Tahu Dan Tempe. Jakarta Selatan: Agromedia. 2007.

[7] Hanafiah, K., A. Rancangan Percobaan Teori dan Aplikasi. Buku. Fakultas Pertanian Universitas Sriwijaya. Palembang. 238 P. 2001.

[8] Layla., N. 2015. Pemanfaatan Tepung Kedelai Sebagai Bahan Substitusi Sus Kering Tepung Mocaf Dengan Variasi Penambahan Jahe. Biology Education Program, Thesis, Surakarta: FaculTy Of Teacher Training And Education, University Of Muhammadiyah Surakarta.

[9] Mandal S, Dahuja A, Kar A, and Santha IM. In vitro kinetics of soybean lipoxygenase with combinatorial fatty substrates and its fungsional signisficance in of flavor development. Food chem..., 146:394-403. 2014.

[10] Mulyani T., Djajati S., Dwi L. R.. Pembuatan Cookies Bekatul (Kajian Proporsi Tepung Bekatul dan Tepung Mocaf) Dengan Penambahan Margarin.
Jurnal Rekayasa pangan, Vol.9 No.2 Desember. 2015.

[11] Napitupulu, Donald S., Terip Karo-Karo. Zulkifli L. Pembuatan Kue Bolu Dari Tepung Pisang Sebagai Subtitusi Tepung Terigu dengan Pengayakan Tepung Kedelai. Jurnal Rekayasa Pangan dan Pertanian. Vol.1 No.4. Penebar Swadaya. Jakarta. $58 \mathrm{hlm} .2013$.

[12] Rahayu, W. P. Petunjuk Penilaian Organoleptik. Fakultas Teknologi Pertanian IPB, Bogor. 1997.

[13] Rao, B., S., N.. Nutritive Value Of Rice Bran. New Delhi. Media Workshop India Pvt Ltd. 2000.

[14] Sudarmadji, S., Bamban, H. Suhardi. Analisis Bahan Makanan dan Pertanian. Liberty. Yogyakarta. 1997.

[15] Suhardjo dan Clara M. Kusharto. Prinsip-Prinsip Ilmu Gizi. Yogyakarta: Penerbit Kanisus. 2002.

[16] Suprapti L. Pembuatan Tempe. Kanisius. Yogyakarta. Suryani. 2006. Bisnis Kue Kering. Penebar Swadaya. Jakarta. 2003.

[17] Swastika, N.D. Tepung Bekatul Melalui Metode Pengukusan dan Pengeringan Rak Serta Pendugaan Umur Simpannya. 2009.

[18] Warisno dan Dahana K. Meraup Untung dari Olahan Kedelai. PT Agro Media Pustaka. Jakarta Selatan. 2010.

[19] Winarno, F.,G.. Kimia Pangan dan Gizi. Jakarta. Gramedia Pustaka Utama. 2004.

[20]Wulandari, M., E Handarsari. Pengaruh Penambahan Bekatul Terhadap Kadar Protein dan Sifat Organoleptik Biskuit. Jurnal Pangan dan Gizi. Vol.o1, No.02. 2010 